\title{
Експериментальна перевірка впливу вібрації на працездатність цифрових датчиків температури для систем комп'ютеризованого забезпечення безпеки AEC
}

- Биковський Юрій Михайлович, канд. техн. наук, проф. ORCID: https://orcid.org/0000-0002-5769-5654

- Дерев'янко Ольга Володимирівна, канд. техн. наук Одеський національний політехнічний університет, м. Одеса, Україна ORCID: https://orcid.org/0000-0002-1472-8292

- Кравченко Володимир Петрович, д-р. техн. наук, проф. Одеський національний політехнічний університет, м. Одеса, Україна ORCID: https://orcid.org/0000-0002-7557-3327

- Левченко Віталій Вікторович Відокремлений підрозділ «Запорізька атомна електрична станція» Державного підприємства «Національна атомна енергогенеруюча компанія «Енергоатом», м. Енергодар, Україна ORCID: https://orcid.org/0000-0002-0391-9907

- Погосов Олексій Юрійович, д-р. техн. наук, проф.

Одеський національний політехнічний університет, м. Одеса, Україна ORCID: https://orcid.org/0000-0002-1942-2612

Стаття містить результати експериментального стендового дослідження роботи цифрового інтелектуального датчика температури DS18B20 в умовах вібраційних впливів, притаманних роботі обладнання атомних електростанцій. Розглянуто питання цифрової алгоритмічної обробки вихідного сигналу датчика для комп'ютеризованого виявлення інформаційних ознак стану обладнання в умовах впливу віброперешкод на первинний вимірювальний перетворювач. Докладно описано розроблений для досліджень експериментальний стенд, наведено методику проведення стендових експериментів і результати застосування цифрової алгоритмічної обробки вимірювальних сигналів з використанням вейвлет-перетворення.

Ключові слова: безпека АЕС, моніторинг і контроль, вимірювання температури, цифровий термодатчик, комп'ютеризована обробка сигнальної інформації.

() Биковський Ю. М., Дерев'янко О. В., Кравченко В. П., Левченко В. В., Погосов О. Ю., 2021

\section{Вступ}

Виробничий технологічний процес такого складного, масштабного і багатокомпонентного енергогенеруючого підприємства, яким $\epsilon$ атомна електростанція (АЕC), неминуче супроводжується механічною вібрацією того чи іншого обладнання, зокрема - обладнання, яке належить до елементів інформаційних та керуючих систем, важливих для безпеки за класифікацією НП 306.2.141-2008 [1]. Варто враховувати, що фактор вібраційного 
впливу може чинити негативний вплив на якість функціонування пов'язаної 3 обладнанням апаратури, включно із засобами інформаційнометрологічного забезпечення систем безпеки (зокрема, елементами систем вимірювання, контролю та моніторингу).

В умовах енергетичного виробництва, потенційно небезпечного в ядерному і радіаційному відношенні, непередбачені аномалії в роботі первинних вимірювальних перетворювачів, сигнально пов'язаних із різними системами безпеки, можуть призвести до аварійних ситуацій і вкрай важких (аварійних) наслідків через недостовірне або неповне інформаційне забезпечення ухвалення рішень. У науково-технічній літературі особливу увагу приділяють сейсмостійкості тепломеханічного обладнання і трубопроводів, що вказує на те, що вібраційні впливи на обладнання цілком очікувані і закономірні [2]. Водночас, недостатня вивченість реакції приладів збору вимірювальної інформації на притаманні обладнанню неспецифічні (фактичні та очікувані) зовнішні вібромеханічні впливи стримує застосування на AEC деяких сучасних датчиків. Повною мірою ця обставина стосується цифрових датчиків температури, які мають працювати в умовах вібрацій: отже, на цій підставі впровадження їх в експлуатацію стримується, хоча вони мають низку суттєвих переваг перед традиційно використовуваними аналоговими засобами контролю і моніторингу технологічних параметрів [3].

Об'єктом цієї статті $\epsilon$ цифровий інтелектуальний датчик температури DS18B20 [4], що розглядається як активний функціональний елемент сучасної вимірювальної технології «1-Wire», впровадження якої на AEC $\epsilon$ перспективним через повсюдний перехід на комп'ютерні системи управління технологічним обладнанням АEC [5]-[7]. Предметом статті $€$ властивості датчика, які проявляються в сигнальному відгуку датчика в умовах вібраційних впливів.

Вимірювальна технологія («1-Wire») дозволяє створювати багатовимірні вимірювальні мережі 3 використанням десятків і сотень подібних датчиків і на цій основі забезпечувати недосяжний раніше ступінь інформатизації систем забезпечення безпеки AEC - завдяки оперативному отриманню та аналізу більш широкої й детальної інформації про розподіл температурних полів, характерних для станційного тепломеханічного обладнання.

Доцільність та практична зацікавленість у використанні цифрових датчиків DS18B20 і технології «1-Wire» на AEC зрозуміла, наприклад, з огляду на виробничу необхідність регулярного термометричного контролю і моніторингу паротурбінної установки енергоблока. Вимірювання температури елементів турбоагрегату традиційними засобами (лише в нині прийнятих контрольних точках) не дає повної картини теплового стану турбоагрегату і не дозволяє об'єктивно оцінювати рівень його поточної функціональної надійності. Застосування мережевої цифрової концепції вимірювального контролю і моніторингу температурних полів може значно збільшити інформативність вимірювань, необхідну для забезпечення безпечного функціонування технологічного устаткування енергоблока. Зауважимо, що робота турбоустановки неминуче пов'язана з механічними вібраціями, які не можуть не впливати на температурні датчики, якими вона повинна бути оснащена.

Дійсно, рухомою частиною парової турбіни $\epsilon$ валопровід (сукупність з'єднаних між собою роторів послідовно розташованих циліндрів), частота обертання якого становить 1500 об/хв або 3000 об/хв (залежно від типу турбіни) [8]. У процесі експлуатації турбоагрегату AEC (у стаціонарному режимі і особливо під час нестаціонарних режимів роботи) закономірно виникають вібрації, причому вібраційний стан агрегату вважається прийнятним і допустимим, якщо він задовольняє певні вимоги [9], [10]. Так, середньоквадратичні значення віброшвидкості в зоні опор підшипників турбін потужністю 100 МВт і більше не повинні перевищувати 4,5 мм/с у всіх напрямках, а амплітуда вібрацій (розмах вібропереміщень ротора) не повинна бути більша 165 мкм при частоті обертання 50 Гц і 200 мкм - при частоті обертання 25 Гц.

Незважаючи на прийнятність значень амплітуд і частот допустимих вібрацій турбоагрегату, відповідних згаданим вище межам вібропараметрів у режимах нормальної експлуатації, вібрація може бути несприятлива для засобів вимірювальної техніки. В аномальних же (передаварійних і аварійних) режимах, коли будь-яка достовірна вимірювальна інформація «росте в ціні», вібраційні параметри можуть значно перевищувати нормальні (встановлені) межі, і апріорі важливо знати ліміт можливостей отримання достовірної сигнальної інформації, постачальником якої $\epsilon$ встановлені на обладнанні датчики, а споживачем - система ухвалення рішень і забезпечення безпеки. Температурні датчики $\epsilon$ важливими постачальниками сигнальної інформації на AEC i, можна припустити, що не всі датчики температури $\epsilon$ однаково прийнятними для використання в таких умовах.

Зазначимо, що на AEC $\epsilon$ чимало технічних об'єктів (наприклад, насоси, вентилятори, компресори, трубопроводи тощо), вібрації яких, на відміну від вібрацій турбоагрегату, регламентовані значно менш жорстко, і під час оснащення їх цифровими датчиками температури питання надійності роботи датчиків виявляються ще більш гострими для практики експлуатації і цікавими 3 наукового погляду.

Зауважимо, що метрологічне забезпечення вимірювальною інформацією систем оперативного 
контролю та моніторингу технологічних процесів пов'язане не тільки з необхідністю оснащення обладнання надійними (зокрема вібростійкими) первинними вимірювальними перетворювачами температури, але і з використанням ефективних алгоритмів обробки вимірювальних сигналів 3 урахуванням дедалі більшою мірою саме цифрових сигналів у системах інформатизації комп'ютерно-орієнтованих систем забезпечення безпеки AEC [11].

\section{Постановка завдання дослідження} та мета статті

3 огляду на наведені вище положення, які зумовлюють актуальність окресленої проблеми, виконується дослідницьке завдання: вивчити працездатність і функціональну надійність інтелектуальних датчиків температури 3 цифровою обробкою вимірювальних сигналів в умовах вібраційних впливів, враховуючи значущість цих досліджень для подальшої перспективи розвитку системи ефективної інформатизації систем забезпечення безпеки АEC.

Метою досліджень $\epsilon$ проведення стендових експериментів 3 перевірки впливу вібраційних впливів на функціонування стандартних цифрових датчиків температури типу DS18B20 і пошуковий аналіз застосовності вейвлет-перетворення для алгоритмічної обробки сигнальної інформації, одержуваної від датчиків під час експериментальних досліджень.

\section{Проведення експериментальних досліджень}

Засоби стендового фізичного моделювання вібраційних впливів. Для проведення експериментальних досліджень було використано підхід, за якого вібраційний вплив на цифровий датчик розглядався як сукупність короткочасних сил, які створюють статичний тиск на корпус датчика. Під час такого моделювання процесу вібрації, що впливає на датчик температури, були враховані вимоги документа [12].

Зважаючи на це, як стендову установку, що моделює процес вібрації із заданими параметрами, було застосовано лабораторну балансувальну установку конструкції Б. В. Шитікова (установка ТММ-1А) [13]. Стенд призначений для динамічного противібраційного балансування роторів, що зумовлює його конструктивні особливості, які схематично зображені на Рисунку 1.

Під час динамічного балансування ротора масивні елементи, які в початковому положенні $\epsilon$ врівноваженими, поміщають на його торцях, а сам ротор установлюють так (Рисунок 1), щоб площина одного з торців (площина а-а) проходи- ла через опору (точка 0) пружно закріпленої основи. Тоді на коливання ротора впливають лише вантажі-ексцентрики (противаги), встановлені на правому торці ротора.

Пружне закріплення однієї основи ротора досягається з'єднанням її з фундаментом за допомогою пружного елементу (наприклад, пружини), як показано на Рисунку 1. За таких умов, ротор, який обертається під дією неврівноваженої сили (умовно кажучи, сили інерції - відповідно до принципу Германа-Ейлера-Д'Аламбера), буде коливатися у вертикальній площині. Амплітуда коливань буде максимальною під час резонансу, а їі величина може бути зареєстрована відхиленням стрілки С».

Якщо в штатному режимі стенд дозволяє усунути небажаний дисбаланс ротора, спочатку створений через болт, ексцентрично вкручений в один із його торців, то в нашому випадку використовувалася можливість розв'язання оберненої задачі: проведення моделювання різних віброколивань 3 використанням технологічних атрибутів стенда.

Для побудови системи вимірювання і зображення параметрів модельованих вібраційних процесів використовувалися такі функціональні елементи:

первинний датчик-віброперетворювач KD-13 [14];

передпідсилювач - для узгодження параметрів вимірювальної схеми;

осцилограф PV 6501, який був підключений до комп'ютера для зображення отриманого сигналу за допомогою програмного середовища PV6501_FPGA.1 [15].

Організація такої вимірювальної схеми для реєстрації параметрів вібрації дозволяє швидко і наочно реєструвати зміни процесу вібрації в часі, а також виконувати математичні операції з обробки сигналів у реальному масштабі часу та здійснювати імпортування даних у необхідні програмні модулі, наприклад, для їх подальшої обробки в математичному середовищі «Matlab».

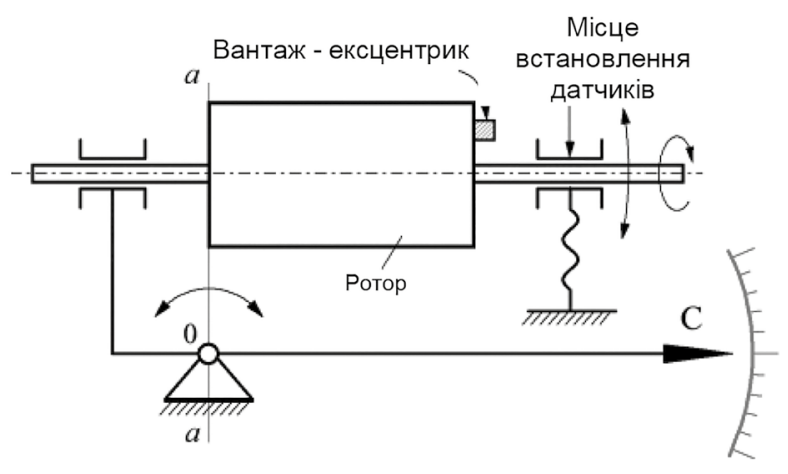

Рисунок 1 - Структурна схема генератора механічних вібрацій 
Віброперетворювач KD-13 (Рисунок 2) являє собою п'єзоелектричний датчик (акселерометр), який здійснює пряме перетворення механічного впливу в електричний сигнал. Принцип роботи датчика базується на згинальній деформації п'єзоелемента, у ролі якого використовується фольгований керамічний шар цирконат-титанату свинцю ЦТС-19. Цим досягається висока осьова чутливість, за низької поперечної. Як зображено на Рисунку 2, конструкція передбачає три види кріплення датчика на об'єкті: різьбове, за допомогою постійного магніту або на зондуючу шпильку для дослідження вібрації у важкодоступних місцях.

Зважаючи на те, що вихідний імпеданс (комплексний опір) віброперетворювача досягає значень, що відповідають електричній ємності від 500 пФ до 3000 пФ для розглянутих частот, на нижній робочій частоті модуль імпедансу може приймати значення в діапазоні від 25 МОм до 100 МОм.

Підготовка апаратури для експериментальних досліджень. Щоб усунути шунтування «високоомного» віброперетворювача вхідними ланцюгами вторинного приладу у вимірювальному каналі віброметра, необхідно було застосувати погоджувальний пристрій, вхідний опір якого значно перевищує (за модулем) імпеданс віброперетворювача. Таким пристроєм у такому разі $є$ попередній (бустерний) підсилювач.

Під час вимірювання віброприскорення, відповідного діапазону з верхнім граничним значенням 1000 m/c ${ }^{2}$, на вхід підсилювача буде надходити сигнал із середньоквадратичним значенням (СК3), рівним:

$$
U_{\text {max }}=a_{\max } \gamma=1000 \times 0,01=10 B,
$$

де $a_{\text {max }}$ - верхнє граничне CКЗ віброприскоренНя, $\mathrm{M} / \mathrm{C}^{2}$;

$\gamma$ - чутливість віброперетворювача, B·c²/M.

Оскільки електричний сигнал (що визначає віброприскорення), який має надходити з реальних (контрольованих) технічних об'єктів, $\epsilon$ випадковим (стохастичним), його амплітуда може бути в 3...10 разів більше СКЗ. Тому приймаємо:

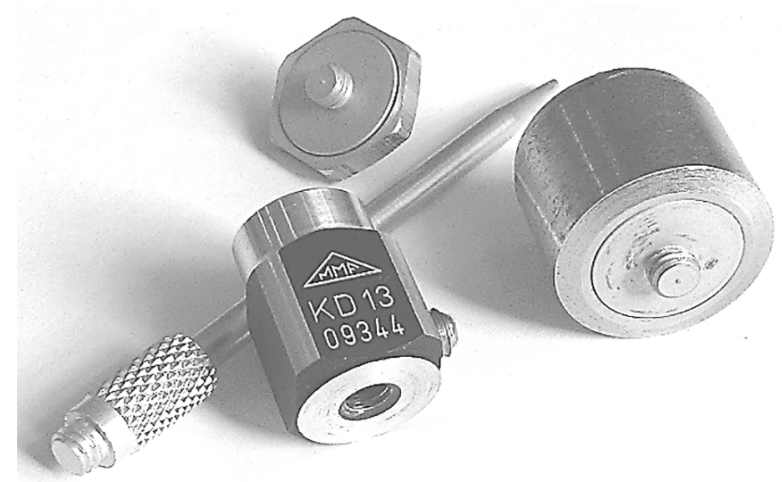

Рисунок 2 - Елементи кріплення датчика KD-13

$$
U_{\text {amp }}=10 \times U_{\text {max }}=100 B,
$$

де $U_{\text {amp }}$ - ймовірне амплітудне значення вхідної (щодо передпідсилювача) сигналу, В.

Під час вимірювання віброприскорення, відповідного нижньому граничному значенню $0,1 \mathrm{~m} / \mathrm{c}^{2}$, на вхід підсилювача буде надходити сигнал, що характеризується СК3:

$$
U_{\min }=a_{\min } \gamma=0,1 \times 0,01=0,001 B
$$

Основна відносна похибка вимірювання рівня вібрації в робочому діапазоні амплітуд і частот не повинна перевищувати $\pm 10 \%$. Загасання вище і нижче меж робочого частотного діапазону має бути не менше 20 дБ [16]. Отже, визначимо відповідне цій вимозі значення допустимої амплітуди шуму, наведене до входу підсилювача:

$$
U_{n}=\frac{U_{\min }}{4}=2,5 \times 10^{-4} B
$$

Вхідний опір підсилювача визначається, $з$ огляду на вимоги мінімального навантаження віброперетворювача, на нижній робочій частоті:

$$
\begin{gathered}
R_{\text {in }} \gg \frac{1 k}{\omega C} \gg \frac{0,16}{f C} ; \\
R_{\text {in }} \frac{10 \times 0,16}{2 \times 1500 \times 10^{-12}}=5330 M,
\end{gathered}
$$

де $R_{\text {in }}$ - вхідний опір підсилювача, Ом;

$k$ - коефіцієнт у межах від 5 до 20;

$\omega, f$ - нижня гранична робоча частота віброметра, виражена в одиницях рад/с та Гц;

С - вихідна ємність віброперетворювача, Ф.

На Рисунку 3 зображено схему підсилювача, розроблену з урахуванням наведених вище вимог.

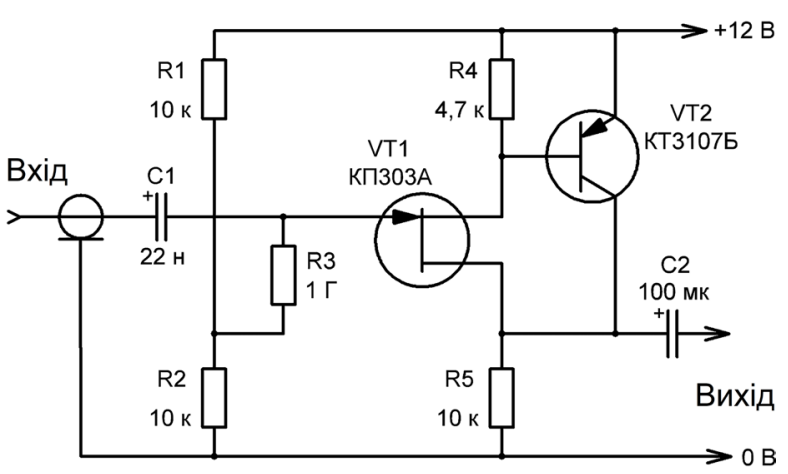

Рисунок 3 - Схема передпідсилювача 


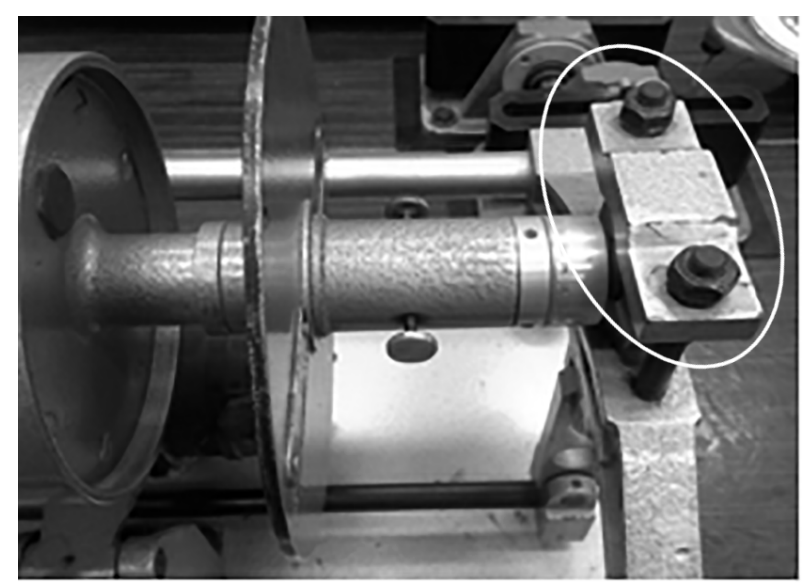

a)

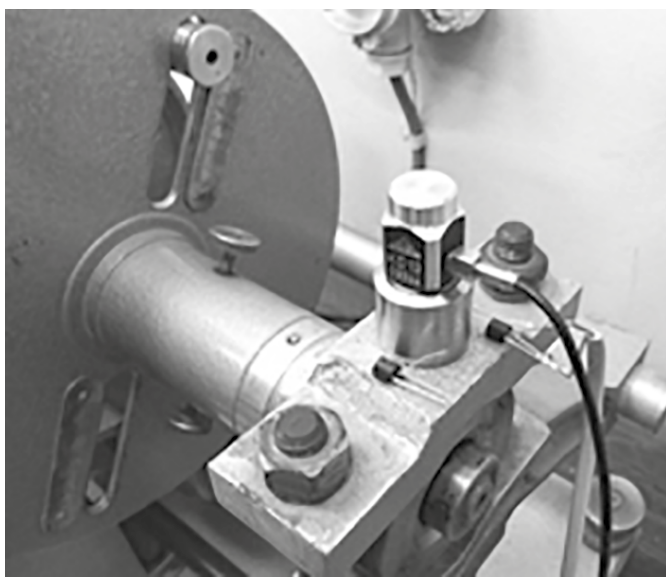

б)

Рисунок 4 - Місце розміщення датчиків (а) і їх фактичне розташування (б)

\begin{abstract}
Монтаж датчиків вібрації KD-13 та температури DS18B20 на вібростенді. Вирішення цього питання визначається як можливостями стенда (Рисунок 1), так і характеристиками датчика вібрації KD-13. Оскільки цей датчик призначений для вимірювання вібрації, співвісної його поздовжній осі, корпус датчика повинен бути орієнтований суворо в площині стендових коливань. Така орієнтація також відповідає вимогам чинних в Україні нормативних документів, що встановлюють характеристики кріплення акселерометрів, а також дає рекомендації щодо установки акселерометрів [17], [18]. У такому разі вимогам і рекомендаціям 3 установки акселерометра на вібростенді відповідає майданчик на верхній опорі правого підшипника ротора (виділено на Рисунку 4, а), куди за допомогою магнітної підставки був установлений датчик KD-13. Тут же, поруч з датчиком KD-13, був закріплений за допомогою клею досліджуваний датчик температури DS18B20 (Рисунок 4, б). Специфіка вібраційних випробувань вимагає застосування кабелів, якнайменше чутливих до зміни своїх характеристик під
\end{abstract}

дією вібрації. У наших дослідах використовувався спеціальний антивібраційний малогабаритний кабель марки АВК-6 [19].

Для того, щоб переконатися, що обраний балансувальний стенд (що застосовується як стендовий генератор механічних вібрацій) створює необхідний рівень вібрації, якого достатньо для відтворення умов, наближених до можливих експлуатаційних умов на АEC, була проведена кількісна оцінка значення параметрів вібрації, які забезпечуються віброгенератором у вихідному дисбалансному стані.

Серія дослідів, проведених в однакових умовах, дозволила за допомогою індикатора годинникового типу ИЧ-10 визначити величини віброамплітуд у момент настання резонансу, середн $\epsilon$ арифметичне значень яких склало АCP = 1,65 мм.

Знання середнього значення амплітуди коливань (1650 мкм), а також значення частоти обертання ротора віброгенератора стенда (37 Гц) дозволило здійснити розрахунок інших параметрів, скориставшись залежностями для визначення віброшвидкості, віброприскорення і вібропереміщення. У Таблиці 1 наведені результати розрахунків.

Таблиця 1 - Результати визначення параметрів вібрації стенда

\begin{tabular}{|l|c|}
\hline \multicolumn{1}{|c|}{ Параметр } & Значення \\
\hline СК3 віброприскорення & $63,1 \mathrm{~m} / \mathrm{c}^{2}$ \\
\hline Амплітуда віброприскорення & $89,2 \mathrm{~m} / \mathrm{c}^{2}$ \\
\hline СК3 віброшвидкості & $271,2 \mathrm{~mm} / \mathrm{c}$ \\
\hline Амплітуда віброшвидкості & $383,6 \mathrm{~mm} / \mathrm{c}$ \\
\hline СК3 вібропереміщення & $1167,0 \mathrm{mKM}$ \\
\hline Розмах вібропереміщення & $3300,0 \mathrm{mKM}$ \\
\hline
\end{tabular}




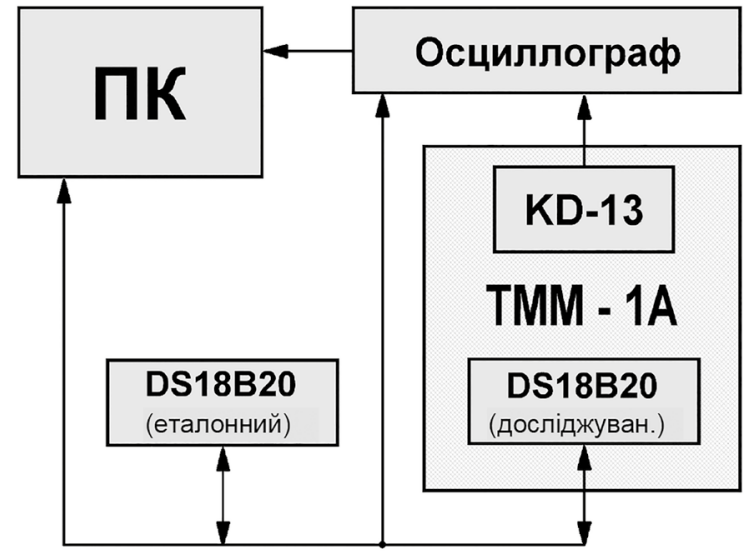

Рисунок 5 - Структурно-методична схема експериментальної установки

Отримані величини перевищують допустимі норми вібрації для машин та механізмів, наведені вище, отже, стендова балансувальна установка TMМ - 1A, має ширші технічні можливості, і повністю підходить, за нашими оцінками, для проведення вібраційних випробувань датчика температури DS18B20 як об'єкта дослідження.

Для проведення експериментів, з огляду на технічні можливості стенда, була зібрана схема, показана на Рисунку 5, основними елементами якої $\epsilon$ :

ПК - програмований контролер (або персональний комп'ютер) для збору і обробки отриманих даних від осцилографа і датчиків температури;

осцилограф - для зображення сигнальної інформації від датчиків температури і акселерометра;

KD-13 - датчик для вимірювання параметрів вібрації;

DS18B20 (еталонний) - для вимірювання температури поза зоною впливу вібрації;

DS18B20 (досліджуваний) - для вимірювання температури в зоні впливу вібрації.
Методика і процедура експериментальних досліджень. У методичному відношенні експериментальні дослідження проводилися поетапно, причому основними етапами були:

виявлення наявності вібрації, у складі цифрового сигналу показів датчика температури;

виявлення інформаційної ознаки вібраційного впливу у вихідному сигналу датчика температури.

Для проведення першого етапу експериментів обидва датчика температури DS18B20 (еталонний та досліджуваний) були підключені до вторинної апаратури за протоколом «1-Wire» відповідно до структурно-методичної схеми (Рисунок 5). Один із датчиків (досліджуваний) розташовувався на стенді безпосередньо поруч із датчиком вібрації KD-13 (Рисунок 4,6), а другий (еталонний) був установлений на відстані, яка усуває відхилення температури середовища, спричинені роботою стенда.

Покази температури відображалися на моніторі ПК за допомогою програми Temp.Keeper [20]. На Рисунку 6 показані отримані криві зміни температури, виміряні обома датчиками, за довільно обраний проміжок часу.

Як видно на Рисунку 6, криві вимірювання температури мають схожий характер, температура на досліджуваному датчику під час випробування змінювалася симетрично (статистично ідентично) показанням еталонного датчика, залежно від флуктуацій температури навколишнього середовища (невеликі відмінності можна пояснити наявністю основної абсолютної похибки датчиків). Загалом, відмінності показів температурних датчиків не перевищують допустимих значень похибки $\pm 0,5^{\circ} \mathrm{C}$, заявлених виробником датчиків [4]. Результат експериментального дослідження на цьому (описаному) етапі дозволив зробити висновок, що досліджуваний датчик DS18B20 не $\epsilon$ чутливим до впливу вібрації в межах значень параметрів, зазначених в Таблиці 1.

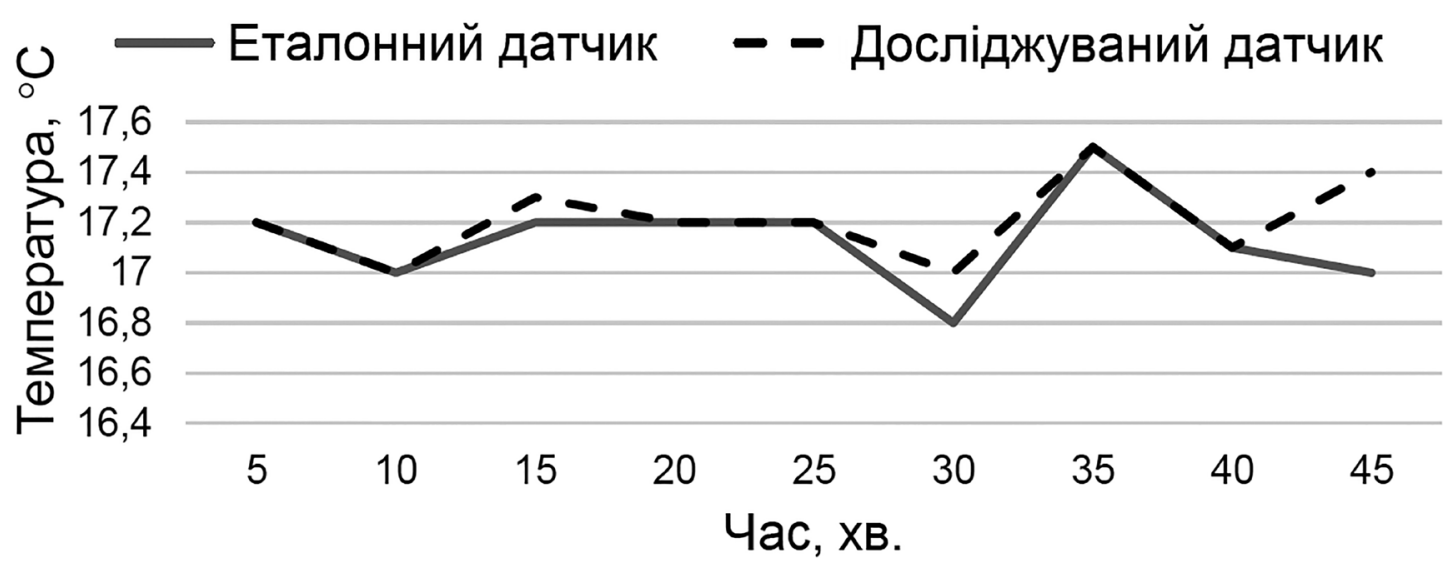

Рисунок 6 - Характер сигналів від датчиків DS18B20 
Для проведення другого етапу дослідження по черзі підключали до входу осцилографа датчик температури та віброперетворювач KD-13. Дослідження проводилися в чотирьох режимах: початковий дисбаланс, дисбаланс відповідний 30\%, $60 \%$ та $100 \%$ від максимально можливого - задля забезпечення необхідного за методикою вібраційного впливу.

У кожному з проведених дослідів, після формування імпульсу скидання, за допомогою цифрового осцилографа PV 6501 реєструвалися і запам'ятовувалися для подальшої обробки реалізації сигналів (вибірки). Для отримання максимально точних результатів перед їх подальшою аналітичною обробкою отримані осцилограми (реалізації сигналів) були очищені (відфільтровані) від сигнального «шуму» за допомогою вейвлет-фільтрів [21]-[23]. Відфільтровані реалізації склали банк даних для подальшого аналізу експериментально отриманих результатів.

\section{Аналіз результатів експериментальних досліджень}

Аналіз осцилограм сигналів від віброперетворювача проводився з використанням безперервного вейвлет-перетворення (continuous wavelet transform). На Рисунку 7 наведені реалізації сигналів на виході віброперетворювача.

На Рисунках 8 - 11 показані вейвлет-перетворення цих сигналів (у форматі скріншот).
На Рисунках 8 - 11 білим контуром виділені області, які дозволяють виявити інформаційну ознаку наявності складових вібрації в досліджуваному сигналі. Причому, інтенсивність прояву вібрації також добре простежується в сигналі (наприклад, під час $100 \%$ впливу маємо найбільшу область білого кольору). Той же аналітичний інструмент вейвлет-перетворень для обробки сигналів був застосований і для отриманих осцилограм сигналів від досліджуваного датчика температури. На Рисунку 12 наведені реалізації сигналу від датчика температури DS18B20, отримані методом, викладеним у роботі [24].

У процесі розгляду та аналізу заднього фронту імпульсів можна помітити, що тривалість імпульсів не залежить від величини амплітуди вібрації, що моделюється в стендових умовах. Тенденції збільшення або зменшення тривалості сигналу відгуку з посиленням вібраційних впливів також виявлено не було.

Якісний аналіз результатів стендових досліджень показав, що всі вейвлет-перетворення сигналів, отриманих під час експериментів від віброперетворювачів, $\epsilon$ однотипними, і в першому наближенні відмінності в них несуттєві (у всякому разі - аналіз, зроблений під час проведення експерименту, відмінностей виявити не дозволив).

На Рисунку 13 показані результати репрезентативного вейвлет-перетворення сигналу, отриманого від датчика температури.
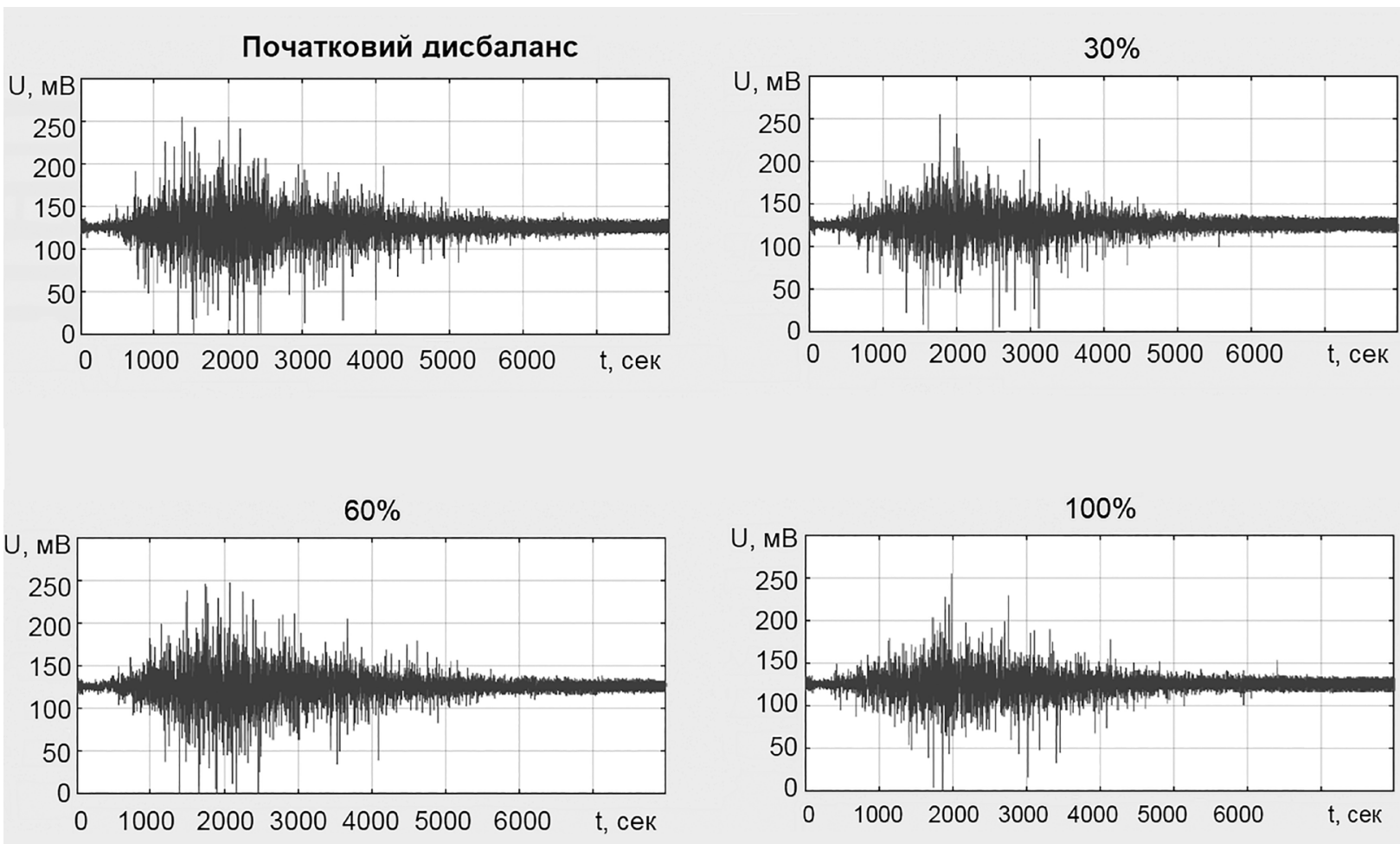

Рисунок 7 - Вихідні сигнали віброперетворювача 

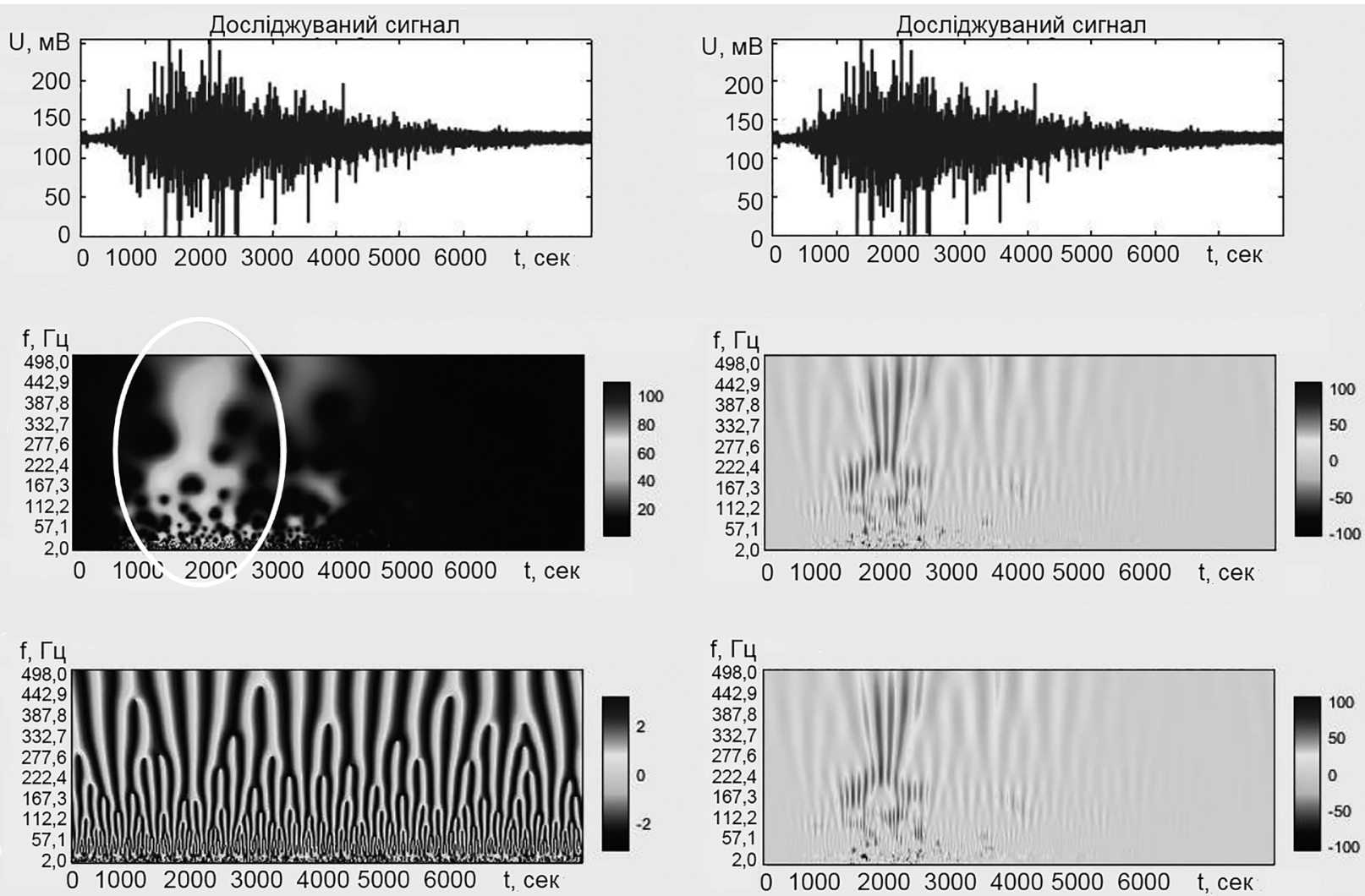

Рисунок 8 - Вейвлет-перетворення сигналу віброперетворювача під час початкового дисбалансу
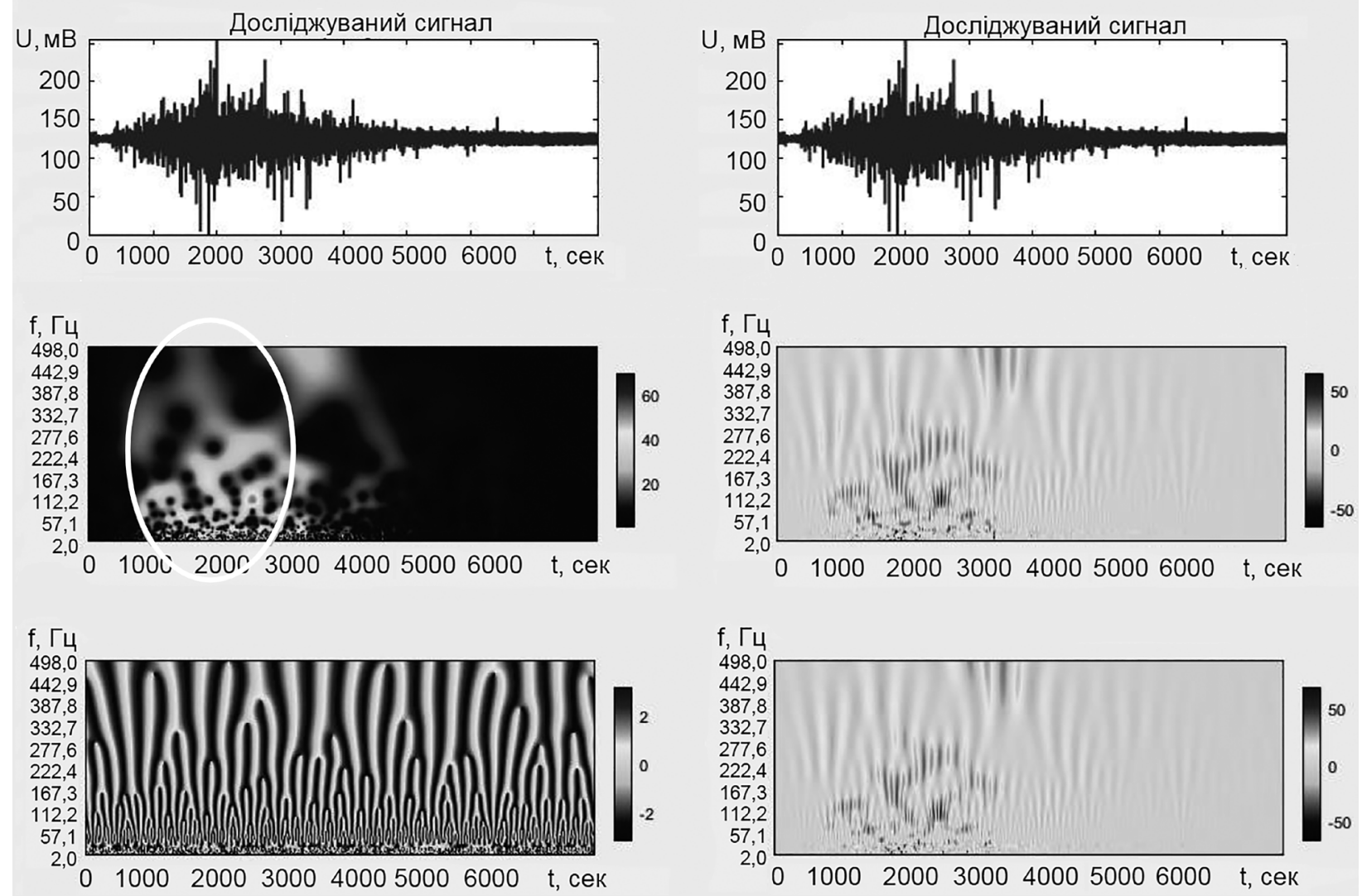

Рисунок 9 - Вейвлет-перетворення сигналу віброперетворювача під час 30 \% впливу 

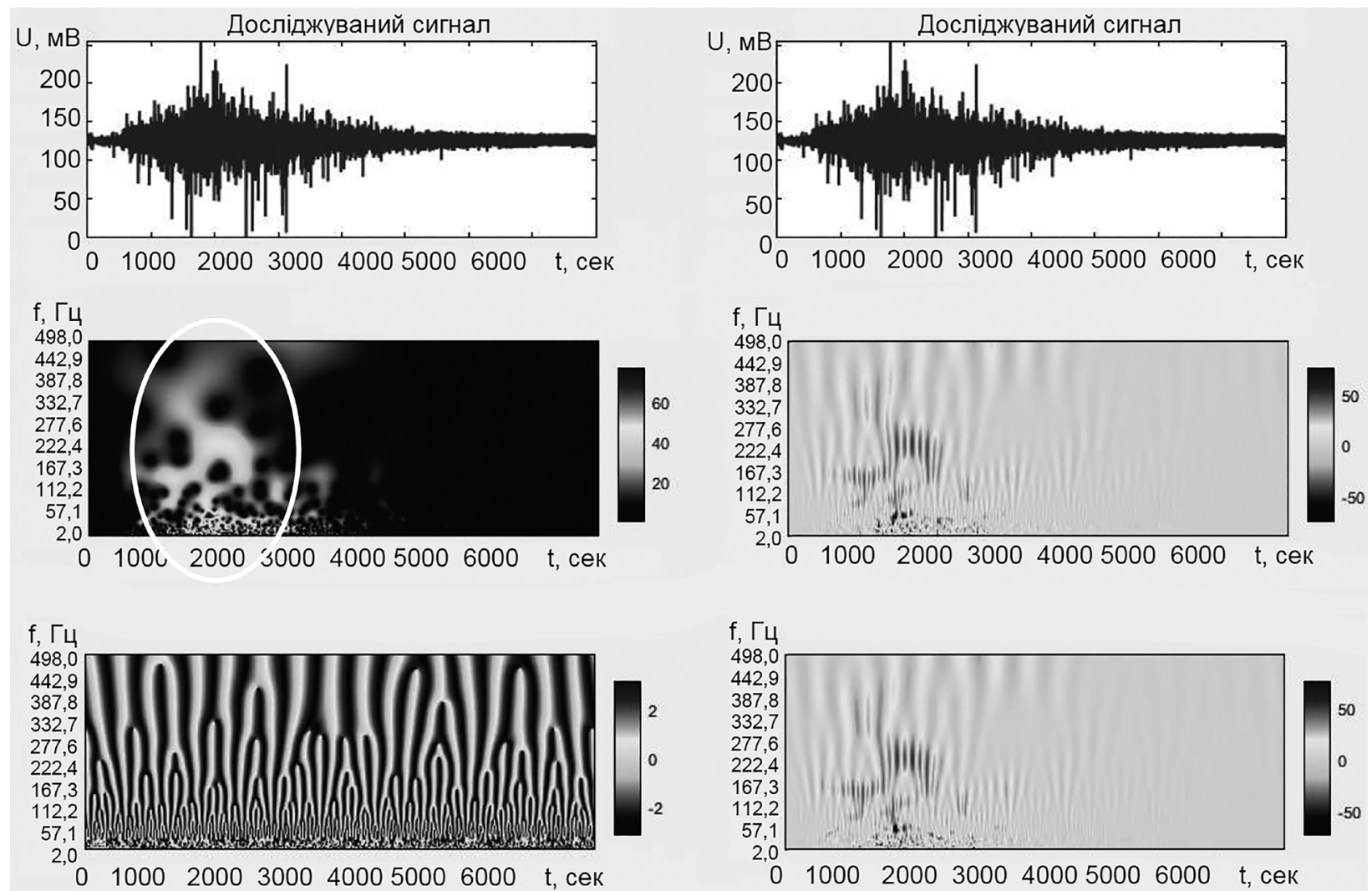

Рисунок 10 - Вейвлет-перетворення сигналу віброперетворювача під час $60 \%$ впливу
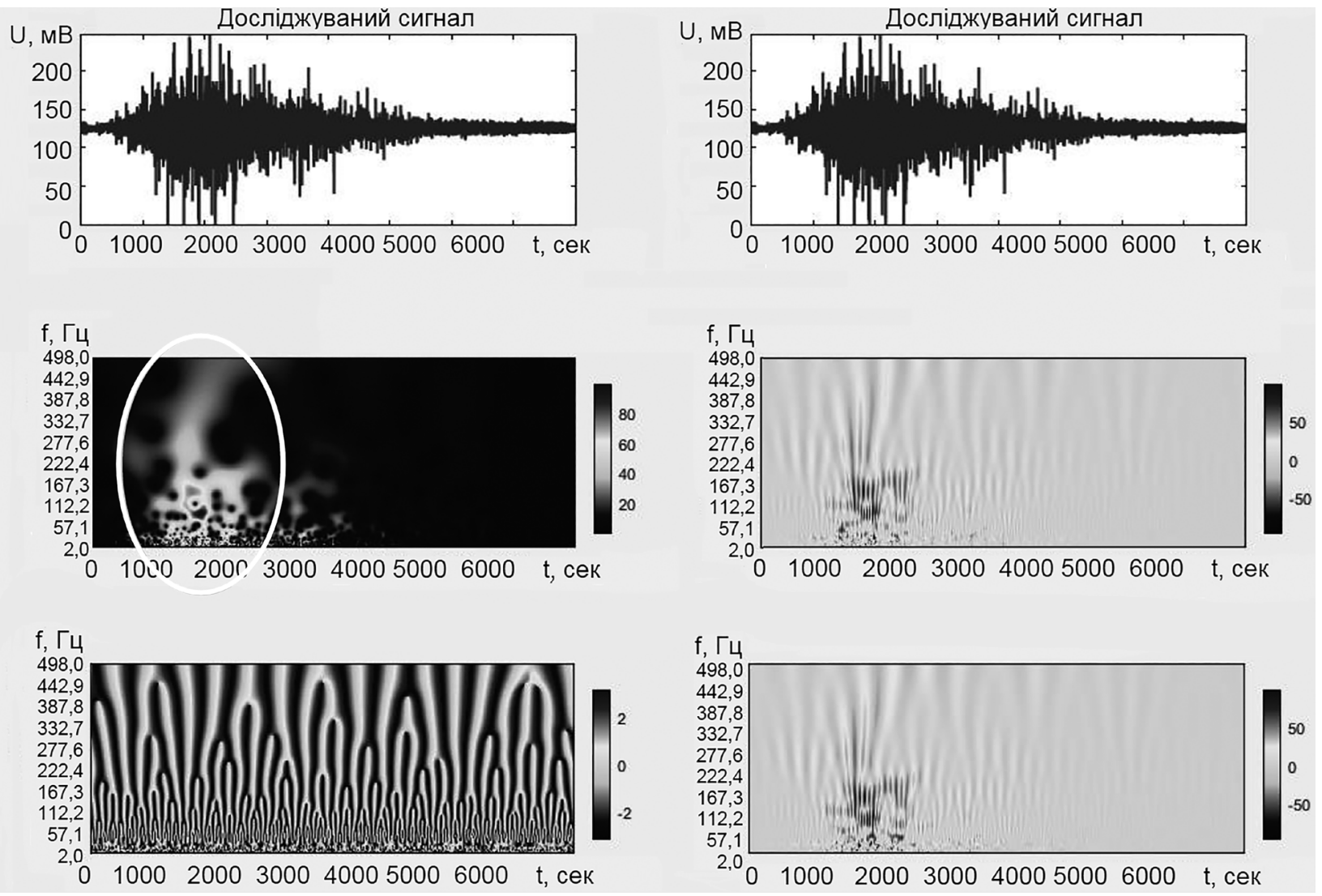

Рисунок 11 - Вейвлет-перетворення сигналу віброперетворювача під час 100 \% впливу 

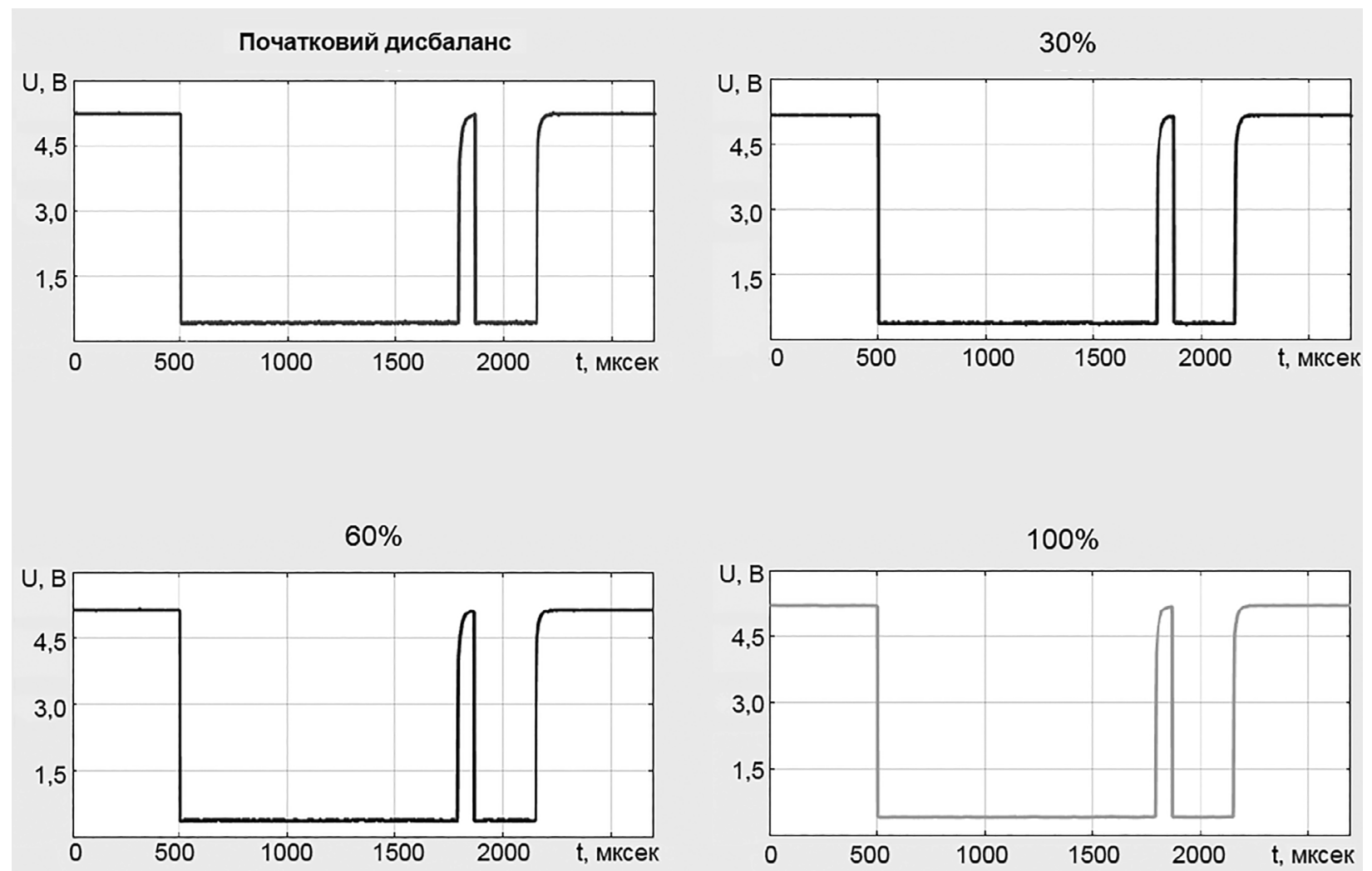

Рисунок 12 - Сигнали датчика температурипід час 30 \% впливу

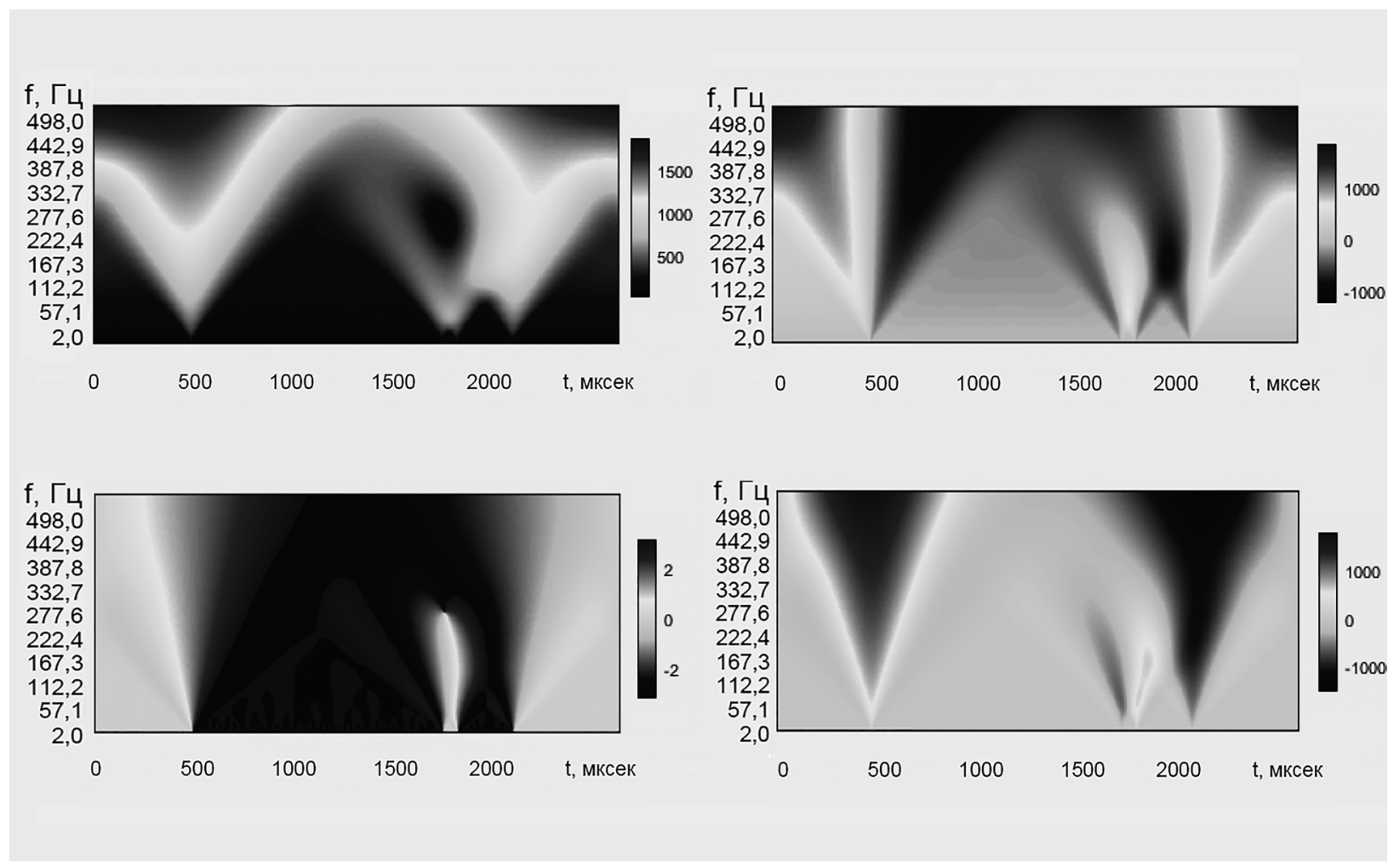

Рисунок 13 - Вейвлет-перетворення сигналу датчика температури 
у порядку аналізу результатів обробки сигнальної інформації зазначимо, що вейвлетперетворення як інструмент аналізу сигналів був обраний з огляду на те, що вейвлети здатні виявляти відмінність у характеристиках на різних шкалах (частотах), а за допомогою зсуву - проаналізувати властивості сигналу в різних точках на всьому досліджуваному інтервалі. Тому, під час аналізу нестаціонарних сигналів, за допомогою властивості локальності вейвлетів, отримують суттєву перевагу перед перетворенням Фур'є, яке дає тільки глобальні відомості про частоту (масштаби) аналізованого сигналу, оскільки використовується при тому система функцій (комплексна експонента або синуси і косинуси) визначена на нескінченному інтервалі.

Можна констатувати, що застосування безперервного вейвлет-перетворення, яке широко використовується під час вирішення задач інтерпретації вимірювальних сигналів від датчиків, в умовах розглянутої задачі, як і в деяких інших випадках [25], не $є$ беззастережно прийнятним та залежить від інтуїції і досвіду дослідника під час інтерпретації результатів первинного вимірювального перетворення [26]. Тому, в цьому разі, такий вид аналізу вимірювальних сигналів не може бути безумовно рекомендованим як надійний інструмент - особливо під час аналізу стаціонарних вібростохастичних впливів. Перевірка застосовності аналітичного інструментарію вейвлет-перетворень за результатами проведеного стендового експериментування над цифровими датчиками виявила необхідність у пошуку додаткових алгоритмічних процедур виявлення ознак стану обладнання для умов стаціонарних вібраційних впливів на цифрові датчики температури. Ця обставина виявиться більш значимою, якщо задача застосування температурних цифрових датчиків на AEC буде розширена від звичайного моніторингу до діагностування процесів, властивих станційному обладнанню, на основі інтерпретації температурних вимірювань.

Водночас, незалежно від алгоритмів комп'ютеризованої інтерпретації сигналів, що надходять від цифрових датчиків температури DS18B20, ці засоби температурного контролю можуть бути застосовані в інформатизованих системах безпеки нового покоління на AEC, з огляду на їх стабільну роботу в умовах вібраційних навантажень.

\section{Висновки}

У результаті проведених стендових експериментів з вивчення впливу вібрації на роботу датчика температури DS18B20 було встановлено таке, незважаючи на те, що параметри вібрації під час фізичного моделювання вібромеханічних процесів на AEC перевищували всі нормативно встановлені межі для машин і механізмів, які застосовуються в енергетичному виробництві, виявити вплив вібрації на працездатність датчика не вдалося. Вібрація також не вчинила ніякого помітного впливу на значення вихідних сигналів досліджених цифрових датчиків температури, тобто не стала фактором зниження їх метрологічної надійності.

Перспективою подальших експериментальних досліджень розглянутих засобів метрологічного забезпечення безпеки АEC може стати тестування цифрових температурних датчиків у промислових умовах експлуатації, а також оцінка застосовності вейвлет-перетворення для випадків нестаціонарності вібрацій і нестаціонарності сигналів температури в перехідних режимах, 3 використанням теорії розпізнавання образів для інтерпретації результатів вимірювань температури $з$ діагностичною метою під час відповідної алгоритмічної обробки вимірювальних сигналів.

\section{Список використаної літератури}

1. НП 306.2.141-2008. Загальні положення безпеки атомнихстанцій.Затвердж.наказом Держатомрегулювання України від 19.11.2007 р. № 162, зареєстр. в М-ві юстиції України 25.01.2008 р. за № 56/14747.

2. Шугайло О-р П., Рижов Д.І., Мустафін М. А., Підгаєцький Т. В., Лєткова Н. Г. Окремі аспекти практичного використання нормативних вимог до сполучення експлуатаційних та сейсмічних навантажень для тепломеханічного обладнання та трубопроводів. Ядерна та радіачійна безпека. 2019. № 4(84). С. 5-11. doi: 10.32918/ nrs.2019.4(84).01.

3. Pogosov A. Yu., Levchenko V. V., Bikovsky Yu. M. Analysis of Prospects for Application of Intellectual Digital Temperature Sensors in Data Channels of On-Line Control Means at Nuclear Power Plants. 2019 IEEE 6th International Conference on Energy Smart Systems (ESS), Kyiv, Ukraine. Kyiv, 2019. P. 76-79. doi: 10.1109/ESS.2019.8764198.

4. DS18B20 High-Precision 1-Wire Digital Thermometer. Data sheet.

5. Canete, J. F., Galindo, C., Garcia-Moral, I. System Engineering and Automation: An Interactive Educational Approach. Berlin: Springer, 2011. 266 p.

6. Design of Instrumentation and Control Systems for Nuclear Power Plants, IAEA Safety Standards Series No. SSG-39. Vienna: IAEA, 2016. $161 \mathrm{p}$.

7. Maxim Integrated. 1-Wire. URL: https://www.maximintegrated.com/en/products/digital/onewire.html (дата звернення: 17.03.2020). 
8. Трухний А. Д., Ломакин Б. В. Теплофикационные паровые турбины и турбоустановки. М.: Издательство МЭИ, 2002. C.60-80.

9. ГОСТ 25364-97. Агрегаты паротурбинные стационарные. Нормы вибрации опор валопроводов и общие требования к проведению измерений. Минск: Межгосударственный совет по стандартизации, метрологии и сертификации, 1998. 8 с.

10. ГОСТ 27165-97. Агрегаты паротурбинные стационарные. Нормы вибрации валопроводов и общие требования к проведению измерений. Минск: Межгосударственный совет по стандартизации, метрологии и сертификации, 1998. 13 с.

11. Бутова О. М., Клевцов О. Л., Печериця О.В., Трубчанінов С.О., Ястребенецький М.О. Аналіз експлуатаційних подій, викликаних дефектами цифрових інформаційних та керуючих систем атомних електростанцій. Ядерна та радіаційна безпека. 2019, № 2(82). C.47-53, doi: 10.32918/nrs.2019.2(82).09.

12. дСтУ гОСт ИСО 10816-1:2007. Вібрація. Контроль стану машин за наслідками вимірювань вібрації на частинах, що не обертаються. Частина 1. Загальні вимоги (ГОСТ ИСО 10816-1-97, IDT; ISO 10816-1:1995, MOD).

13. Шитикова балансировочный станок. Энциклопедия по машиностроению XXL. Оборудование, материаловедение, механика. URL: http://mash-xxl.info/ info/370/ (дата звернення: 15.04.2020).

14. Kennblatt fur schwingungsaufnehmer. Calibration chart for accelerometer typ KD-13. Паспорт датчик колебний.

15. PV-6501. URL: http://www.pv65.ru/ (дата звернення: 15.04.2020).

16. СОУ НАЕК 018:2012. Экплуатация технологического комплекса. Нормы вибрациононого состояния вращающихся механизмов АЭС. Затвердж. наказом ДП «НАЕК «Енергоатом» від 29.10.2012 № 925.

17. ДСТУ ISO 5348:2009. Вібрація та удар механічні. Кріплення акселерометрів механічне (ISO 5348:1998, IDT).

18. ДСТУ ГОСТ ISO 2954:2005. Механічна вібрація машин 3 вертально-поступним і обертовим рухом. Вимоги до засобів вимірювання жорсткості вібрації (ISO 2954:1975, IDT).

19. ТУ 16-505.982-77. Кабели антивибрационные теплостойкие с фторопластовой изоляцией.

20. Temp.keeper. Temperature control and monitoring. URL: https://isens.ru/ (дата зверенення: 20.04.2020).

21. Vetterli M., Kovačević J., Goyal V. K. Foundations of signal processing. Cambridge University Press, 2014. 738p.

22. Addison P.S. The illustrated wavelet transform handbook: Introductory Theory and Applications in Science, Engineering, Medicine and Finance. Boca Raton: CRC Press., 2002. $368 \mathrm{p}$.

23. Яковлев А. Н. Введение в вейвлет-преобразования. Новосибирск: Новосибирский государственный технический университет, 2003. С. 58-64.

24. Быковский Ю.М., Левченко В.В. К оценке возможности применения цифровых датчиков в каналах измерения температуры на АЭС Украины. Сборник научных трудов Севастопольского национального университета ядерной энергии и промышленности. 2010. № 3(35). C. 9-15.
25. Дьяконов В., Абраменкова И. MATLAB. Обработка сигналов и изображений. Специальный справочник. СПб.: Питер, 2002. 608 с.

26. Погосов А. Ю., Деревянко О.В. Метрологическое обеспечение эксплуатации АЭС. Одесса: Наука и техника, 2016. 204 c.

\section{References}

1. NP 306.2.141-2008. General safety provisions for nuclear power plants approved by SNRIU Order No. 162 of 19 October 2007 and registered in the Ministry of Justice of Ukraine on 25 January 2008 under No. 56/14747.

2. Shugaylo, O-r., Ryzhov, D., Mustafin, M., Pidhayetskyi, T., Letkova, N. (2019). Some Aspects of Practical Application of Regulatory Requirements Related to Operating and Seismic Load Combinations for Thermomechanical Equipment and Piping. Nuclear and Radiation Safety, 4 (84), 5-11. doi:10.32918/ nrs.2019.4(84).01.

3. Pogosov, A., Levchenko, V., Bikovsky, Yu. (2019). Analysis of prospects for application of intellectual digital temperature sensors in data channels of on-line control means at nuclear power plants,2019 IEEE 6th International Conference on Energy Smart Systems (ESS), Kyiv, Ukraine, 76-79. doi:10.1109/ ESS.2019.8764198

4. DS18B20 High-precision 1-wire digital thermometer. Data sheet.

5. Canete, J. F., Galindo, C., Garcia-Moral, I. (2011). System engineering and automation: an interactive educational approach. Berlin, Springer, $266 \mathrm{p}$.

6. IAEA Safety Standards Series No. SSG-39. (2016). Design of instrumentation and control systems for nuclear power plants. Vienna, IAEA. 161 p.

7. Maxim integrated. (2020). Guide to 1-WIRE communication. Retrieved March 17, 2020, from: https://www.maximintegrated.com/en/products/digital/onewire.html

8. Trukhny, A., Lomakin, B. (2002). District heating steam turbines and turbine installations. Moscow, MEI Publishing House, 60-80.

9. GOST 25364-97. (1998). Stationary steam turbine units. Vibration standards for shaft line supports and general requirements for measurements. Minsk, Interstate Council for Standardization, Metrology and Certification, $8 \mathrm{p}$.

10. GOST 27165-97. (1998). Stationary steam turbine units. Vibration standards for shaft lines and general requirements for measurements. Minsk, Interstate Council for Standardization, Metrology and Certification, $13 \mathrm{p}$.

11.Butova, O., Klevtsov, O.,Pecherytsia, O., Trubchaninov, S., Yastrebenetskyi, M. (2019). Analysis of operational events caused by faults of NPP digital instrumentation and control systems. Nuclear and Radiation Safety, 47-53. doi:10.32918/ nrs.2019.2(82).09. 
12. DSTU GOST ISO 10816-1:2007 Vibration. Machine condition monitoring based on vibration measurements on non-rotating parts. Part 1. General requirements (GOST ISO 10816-1-97, IDT; ISO 10816-1:1995, MOD).

13. Shytikov's balancing machine. Encyclopedia of mechanical engineering XXL. Equipment, materials science, mechanics. Retrieved April 15, 2020, from : http://mash-xxl. info/info/370.

14. Kennblatt fur schwingungsaufnehmer. (1995). Calibration chart for accelerometer typ KD-13. Vibration sensor certificate.

15. PV-6501. Retrieved April 15, 2020, from: http://www.pv65.ru.

16. SOU NAEK 018:2012. Operation of the technological system. Standards of vibration state of NPP rotating mechanisms approved Energoatom Order No. 925 of 29 October 2012.

17. DSTU ISO 5348:2009. Mechanical vibration and shock. Mechanical fastening of accelerometers. (ISO 5348:1998, IDT).

18. DSTU GOST ISO 2954:2005 Mechanical vibration of machines with progressive and rotational motion. Requirements for tools for vibration severity measurement. (ISO 2954:1975, IDT).

19. TU 16-505.982-77 Heat-resistant anti-vibration cables with fluoroplastic insulation.

20. Temp.keeper. Temperature control and monitoring. Retrieved April 15, 2020, from: http://isens.ru/index.html.

21. Vetterli, M., Kovacevic, J., Goyal, V. (2014). Foundations of signal processing. Cambridge University Press, 738 p.

22. Addison, P., S. (2002). The illustrated wavelet transform handbook: Introductory theory and applications in science, engineering, medicine and finance. Boca Raton, CRC Press, $368 \mathrm{p}$.

23. Yakovlev, A. (2003). Introduction to wavelet transforms. Novosibirsk, Novosibirsk State Technical University, 58-64.

24. Bikovsky, Yu., Levchenko, V. (2010). To an assessment of the possibility of using digital sensors in temperature measurement channels at Ukrainian NPPs. Collection of scientific papers of the Sevastopol National University of Nuclear Energy and Industry, 3 (35), 9-15.

25. Dyakonov, V., Abramenkova, I. (2002). MATLAB. Signal and image processing. Special Reference Book. St. Petersburg, $608 \mathrm{p}$.

26. Pogosov, A., Derevianko, O. (2016). Metrological support of NPP operation. Odessa, Science and Technology, 204 p.

\section{Experimental Verification of the Effect of Vibration on the Performance of Digital Temperature Sensors for NPP Computerized Safety Systems} Bikovsky Yu., Derevianko O.', Kravchenko V.',
Levchenko V.', Pogosov A.'

'Odessa National Polytechnic University, Odessa, Ukraine

${ }^{2}$ Separated entity «Zaporizhzhya NPP» of the National Nuclear Energy Generating Company «Energoatom», Energodar, Ukraine

The paper presents the results of the test bench research of the digital intelligent temperature sensor DS18B20 under vibration effects specific to the operation of NPP equipment. The issue of digital algorithmic processing of the output sensor signal for computerized detection of information signs of equipment state under the impact of vibration interference on the primary measuring transducer is considered. The paper describes in details the test bench developed for studies, presents the technique for bench tests and results of applying digital algorithmic processing of measuring signals with the use of wavelet transformationlt was also found that, despite the fact that the vibration parameters in the physical modeling of vibromechanical processes at NPPs exceeded all regulatory limits for machines and mechanisms used in energy production, the impact of vibration on the sensor could not be detected. These prospects for further experimental studies of the considered means of metrological safety of NPPs can be testing of digital temperature sensors in industrial conditions, as well as evaluation of the applicability of wavelet transform for cases of non-stationary vibrations and non-stationary temperature signals in transient modes, using image recognition theory for interpretation temperature for diagnostic purposes with appropriate algorithmic processing of measuring signals.

Keywords: NPP safety, monitoring and control, temperature measurement, digital temperature sensor, computerized signal information processing. 